\title{
Characterization in primary monolayer culture of separated cell types from rabbit endometrium*
}

\author{
A. P. Ricketts, M. Hagensee and D. W. Bullock \\ Department of Cell Biology, Baylor College of Medicine, Houston, Texas 77030, U.S.A.
}

\begin{abstract}
Summary. Epithelial cells and stromal cells of the rabbit endometrium were separated by successive enzymic digestion of the uterine mucosa. Isolated cell types were obtained in high yield, with good viability, and were maintained in monolayer cultures for up to 2 weeks. Epithelial cells in monolayers appeared as polygonal cells, displayed contact inhibition, and showed the presence of microvilli on the cell surface, with many desmosomes. Stromal cells grew rapidly to confluence, displayed overgrowth, and had a fibroblastic appearance with an absence of junctional complexes between cells. Indirect immunofluorescence showed uteroglobin on the surface of epithelial but not of stromal cells, and only epithelial cells secreted uteroglobin into the medium. These results confirm the identity of the cells and provide biochemical evidence for the epithelial cellular origin of uteroglobin. The method allows the culture of separate endometrial cell types, which retain their morphology and differentiated function in vitro.
\end{abstract}

\section{Introduction}

Formation of a close attachment of the embryo to the uterus is a critical step in the establishment of mammalian pregnancy. The molecular mechanism by which the blastocyst attaches to the endometrial epithelial cells is poorly understood, although it is probably of considerable importance for fertility. Many recognition and adhesion phenomena are thought to involve the cell surface, and our aim is to identify those cell surface components which could play a role in implantation.

Studies of the uterine luminal surface in situ have not described changes related to implantation in precise biochemical terms (Hewitt, Beer \& Grinnell, 1979; Mullins, Horst, Bazer \& Roberts, 1980 ), and a routine method of preparing anatomically defined luminal plasma membrane subfractions has not been described for the uterus as it has been in, for example, liver, kidney and placenta (Glossman \& Gips, 1974; Wisher \& Evans, 1975; Carlson, Wada \& Sussman, 1976). A variety of techniques is available, however, for specifically radiolabelling surface proteins of cells in suspension and monolayer culture, and these have proved to be valuable in uncovering cell surface changes accompanying viral transformation (Hynes, 1973), without the need for subcellular fractionation.

To make use of specific surface-labelling methods, we needed a method of preparing endometrial cells which gave viable cells in high yield that grow well in culture, and which yielded cells with consistent properties at all stages of early pregnancy. The complex cycle of progestational changes in the rabbit endometrium, involving a wave of mitosis, pseudostratification, vascularization, folding, bleb-formation, crowding, ciliation and multinucleation in the epithelium (Davies

* Reprint requests to Dr D. W. Bullock. 
\& Hoffman, 1973) make this last requirement an important one if specific implantation-related changes are to be observed. Furthermore, the technique must allow specific cell types to be cleanly separated and distinguished, and to maintain their differentiated state in vitro.

A collagenase method for dissociating rabbit uterine cells has been described (Gerschenson, Berliner \& Yang, 1974), but it has not been shown to fulfil all the above requirements. A more suitable method is that used for mouse (Sherman, 1978) and rat uterus (McCormack \& Glasser, 1980 ) and we have adapted this latter method for dissociating rabbit endometrium. Isolated uterine cells have been successfully used in studies of steroid receptors (McCormack \& Glasser, 1980), growth regulation (Gerschenson et al., 1974) and in-vitro 'implantation' in blastocyst co-culture (Van Blerkom \& Chavez, 1981), but to our knowledge direct studies describing surface components of separated endometrial cell types through to implantation have not been reported. Such studies using the cell cuiture system described in this report will be published elsewhere.

\section{Materials and Methods}

\section{Primary cell culture}

Female New Zealand White rabbits were obtained as virgin adults from Richglo Laboratory Animals, El Campo, Texas. In non-pregnant animals, absence of corpora lutea was confirmed at hysterectomy, and regardless of other features of ovarian status they were termed Day 0 . Animals for use in pregnancy were tested manually for lordosis and were mated by 2 males consecutively. Pregnancy was confirmed at hysterectomy by the presence of embryos; Day 1 of pregnancy refers to $24 \mathrm{~h}$ after the time of mating.

Collection of uteri and subsequent steps were under aseptic conditions. General anaesthesia was induced by intravenous injection of pentobarbitone sodium, $35 \mathrm{mg} / \mathrm{kg}$ body weight (Nembutal, Abbott Laboratories, Farmer's Branch, Texas, U.S.A.). Uterine horns were severed at the uterotubal junction and cervix and were dissected free of mesometrium; they were blotted free of blood and the uterine lumen at Days 4-6.5 post coitum (p.c.) was flushed $(5 \mathrm{ml}$ per horn) with incomplete (lacking $\mathrm{Ca}^{2+}$ and $\mathrm{Mg}^{2+}$ ) Hank's balanced salt solution (Medium $\mathrm{IH}$ ). Flushings were examined for the presence of embryos. At Day 7 p.c., blastocysts could not be flushed and interimplantation segments of uterus were taken for cell dissociation. The uterine horns were everted and placed into $6.25 \mathrm{ml} 2.5 \%$ (w/v) pancreatin in incomplete Dulbecco's phosphate-buffered saline (Medium ID; GIBCO, Grand Island, New York, U.S.A.) containing $0.5 \%$ trypsin (type III, Sigma Chemical Co., St Louis, Missouri, U.S.A.) on ice. Hysterectomized animals were killed before recovery by intracardiac injection of a lethal dose of pentobarbitone sodium.

Epithelial cells were separated by continuing the incubation in pancreatin/trypsin for $2 \mathrm{~h}$ at $4^{\circ} \mathrm{C}$ followed by $1 \mathrm{~h}$ at $21^{\circ} \mathrm{C}$. The incubations were agitated on a vortex mixer and the cell supernatants were transferred to $0.6 \mathrm{ml}$ fetal calf serum (FCS, heat-inactivated; GIBCO or Irvine Scientific, Santa Anna, California, U.S.A.) plus $0.5 \mathrm{ml}$ Medium ID containing 400 units collagenase (GIBCO, or Sigma type VI). Two further cell supernatants were obtained by vortex-mixing the tissue in $10 \mathrm{ml}$ Medium IH and were pooled with the first supernatant. The cells were incubated with collagenase for $30 \mathrm{~min}$ at $37^{\circ} \mathrm{C}$ with shaking.

Stromal cells were separated from the remaining tissue by transfer to $5 \mathrm{ml} 0.05 \%$ trypsin, $0.02 \%$ EDTA in Medium IH containing 400 units DNase II (type IV, Sigma), and 6 glass beads. The tissue was incubated at $37^{\circ} \mathrm{C}$ with continuous shaking, mixed on a vortex stirer after 7 min and again at the end of incubation after 15 min. Cell supernatants were treated as for epithelial cells.

Both the epithelial and stromal cell fractions after treatment with collagenase were washed by centrifugation at $500 \mathrm{~g}$ for $10 \mathrm{~min}$ and were resuspended in $50 \mathrm{ml}$ Medium IH. Connective tissue was removed by spooling with a glass rod. Cells were centrifuged and resuspended in $15 \mathrm{ml}$ culture medium (Dulbecco's modified Eagle's medium, high glucose, at 10\% FCS and $100 \mathrm{U}$ penicillin $/ \mathrm{ml}$, $100 \mu \mathrm{g}$ streptomycin/ml, GIBCO). Cell suspensions were passed over glass-bead columns (in 30-ml 
plastic syringes), and preparations from separate uterine horns were pooled at this stage. Cell suspensions were placed on ice, and aliquants of $100 \mu \mathrm{l}$ were taken for testing cell viability by the addition of $10 \mu 10.4 \%$ trypan blue in $0.9 \%(\mathrm{w} / \mathrm{v}) \mathrm{NaCl}$, incubation for $10 \mathrm{~min}$ at $21^{\circ} \mathrm{C}$ and counting in a haemocytometer.

Cells were diluted with culture medium to $10^{6}$ trypan blue-negative cells $/ \mathrm{ml}$ and $5 \mathrm{ml}$ of this suspension were plated in 60-mm Falcon tissue culture dishes (Becton Dickinson, Oxnard, California, U.S.A.) which were incubated at $37^{\circ} \mathrm{C}$ under an atmosphere of $5 \% \mathrm{CO}_{2}$ in air. Stromal cultures were observed periodically using an inverted phase-contrast microscope until single cells, but not contaminating epithelial clumps, had attached, then the medium was discarded and fresh medium added. Culture medium was renewed in all the plates at 1- to 2-day intervals and cell morphology was recorded on Polaroid type 665 film. Medium was centrifuged at $800 \mathrm{~g}$ for $15 \mathrm{~min}$ at $4^{\circ} \mathrm{C}$, and the supernatant was frozen for later assay of uteroglobin concentration.

\section{Electron microscopy}

Cells were grown in 60-mm Permanox tissue culture dishes (Lux Scientific Corp., Newbury Park, California, U.S.A.) and were examined by transmission electron microscopy after 6 days in culture. Cells were rinsed in $0 \cdot 1 \mathrm{M}$-Pipes buffer ( $\mathrm{pH} \mathrm{7.4),} \mathrm{fixed} \mathrm{in} 2.5 \%$ glutaraldehyde for $35 \mathrm{~min}$ and post-fixed in $1 \%$ osmium tetroxide for $2 \mathrm{~h}$; they were then dehydrated in ethanol and embedded in Spurr's low viscosity mounting medium. Sections were cut parallel to the plane of the dish and were examined in a Siemens Elmiskop 102 transmission electron microscope.

\section{Histology}

For histological examination of tissue during cell separation, segments of the everted uterine horns were removed with scissors and fixed for $24 \mathrm{~h}$ in Bouin's fixative, then cleared in 3 changes of $70 \%$ ethanol. The tissue was dehydrated, embedded in paraffin wax and $5-\mu \mathrm{m}$ sections were stained using the Masson-Goldner trichrome method (iron haematoxylin; Ponceau-acid fuchsin; azophloxine/light green).

\section{Uteroglobin indirect immunofluorescence}

Cells were grown on $11 \times 22-\mathrm{mm}$ glass coverslips with 3 coverslips per $60-\mathrm{mm}$ culture dish. Cells were rinsed with DPBS, fixed in $3 \%$ formaldehyde (Ultrapure-TEM grade, Tousimis Research Corp., Rockville, Maryland, U.S.A.) in DPBS for $15 \mathrm{~min}$ at room temperature, and rinsed in DPBS. Coverslips were incubated cell-side-down in $50 \mu \mathrm{l}$ of a 1 in 100 dilution of goat antiuteroglobin antiserum (Bullock, Woo \& O'Malley, 1976) for $1 \mathrm{~h}$ at $37^{\circ} \mathrm{C}$ in a humid chamber. The coverslips were rinsed for $30 \mathrm{~min}$ in DPBS then incubated with a 1 in 20 dilution of fluoresceinconjugated rabbit anti-goat-IgG antiserum (Miles Yeda Ltd, Rehovot, Israel) for 30 min, rinsed again in DPBS for $30 \mathrm{~min}$, and mounted in $10 \% \mathrm{DPBS}-\mathrm{NaOH}, \mathrm{pH} 9 \cdot 0$, in glycerol. Fluorescence patterns were recorded using a Leitz Orthoplan epifluorescence microscope, with KP 496, KG 1 and BG 38 filters, on Kodak Tri-X film. Controls were as follows: (1) cells prepared and grown in the absence of FCS, (2) omission of first antiserum, (3) first antiserum substituted by normal goat serum (GIBCO), (4) first antiserum preabsorbed with purified uteroglobin, (5) omission of second antiserum.

\section{Uteroglobin assay by radial immunodiffusion}

Radial immunodiffusion was performed as described by Mancini, Carbonara \& Heremans (1965). Samples of culture medium were dialysed, freeze-dried and reconstituted at 10-fold concentration in $20 \mathrm{mM}$-Tris-barbital buffer, $\mathrm{pH} 8.8$. Plates of $1 \%$ agarose (low $\mathbf{M}_{5,}$ Biorad Laboratories, 
Richmond, California, U.S.A.) were prepared in barbital buffer containing $1 \%$ goat antiuteroglobin antiserum and $0.05 \%$ sodium azide. Sample wells contained $7 \mu 1$ 10-fold-concentrated medium or standard solutions of $0-160 \mu \mathrm{g}$ uteroglobin $/ \mathrm{ml}$ barbital buffer. Plates were incubated at room temperature $\left(21^{\circ} \mathrm{C}\right)$ in a humid chamber for 5 days and precipitin rings were then stained with amido black. Unknown uteroglobin concentrations were calculated from precipitin ring areas of the uteroglobin standards. The sensitivity of the assay was $0.06 \mu \mathrm{g} / \mathrm{ml}$, and inter- and intra-assay coefficients of variation were 13.3 and $19.1 \%$ respectively, based on 6 assays with duplicate determinations (Snedecor, 1952).

\section{Protein and DNA assay}

Protein assay was by the Folin-phenol method (Lowry, Rosebrough, Farr \& Randall, 1951) and DNA determinations, on cells scraped off with a rubber policeman and homogenized in distilled water, were by the diphenylamine method (Burton, 1956).

\section{Results}

\section{Cell separation and culture}

Histological examination of sections of everted uteri during cell separation indicated that epithelium was removed during the first (pancreatin/trypsin) digestion, and stroma was removed during the second (trypsin/EDTA/DNAse) digestion (PI. 1, Figs 1-3). After the two digestion steps, the myometrium remained intact, and some small undissociated regions of endometrium remained at the circumference of the everted uterus.

Plate 2, Figs 4-7 show the appearance under phase-contrast microscopy of cells in suspension and of adherent monolayers. The epithelial suspension consisted of rafts of approximately 50-200 cells of $10-\mu \mathrm{m}$ diameter (Pl. 2, Fig. 4) whereas the stromal fraction was single cells or small clumps of cells $6-12 \mu \mathrm{m}$ in diameter (Pl. 2, Fig. 5). The mean yield of viable epithelial cells from pregnant animals was significantly $(P<0.05, t$ test) higher than that from non-pregnant animals, but other differences were not significant (Text-fig. 1). Attachment of epithelial cells occurred progressively from 24 to $36 \mathrm{~h}$ of culture and of stromal cells from 6 to $24 \mathrm{~h}$, and in both fractions cells from Days 0 and 4 of pregnancy attached more rapidly than did those from Days 6 and 7. Epithelial cells were obtained free of stroma, and the slight contamination of stromal preparations by epithelial cells was removed by the differential plating step in the procedure.

Text-figure 2 shows the growth pattern of cells after plating, based on cell protein and DNA measurements (assuming $5 \cdot 3 \mathrm{pg}$ DNA/cell). Despite different plating densities, cells reached a density of $2-3 \times 10^{6}$ cells per dish by the 2 nd day of culture, and this value, confirmed by direct counting of cells in defined areas of the culture dish, was maintained for at least 3 days. Between Days 2 and 5 in culture, increase in protein content occurred without a corresponding increase in DNA. Epithelial cells grew as cohesive groups of polygonal cells (Pl. 2, Fig. 6), and cell diameter was reduced from 60 to $35 \mu \mathrm{m}$ by the time of confluence, when cells developed brightly refringent borders, but no overgrowth was observed. Stromal cells were fibroblastic (Pl. 2, Fig. 7) and spread rapidly to confluence. With increased cell density, cells became long, spindle-shaped and arranged in parallel, then overgrowth occurred. Little cross-contamination of the different cell types was seen. Epithelial cells differed by stage of pregnancy with respect to the proportion of multinucleate cells observed, which were rarely seen at Days 0 and 4, but were common by Day 7 . The appearance of stromal cells did not vary with stage of pregnancy. Cells have been grown for at least 2 weeks in culture; the experiments described in this paper, however, were performed within the first week. 
PLATE 1
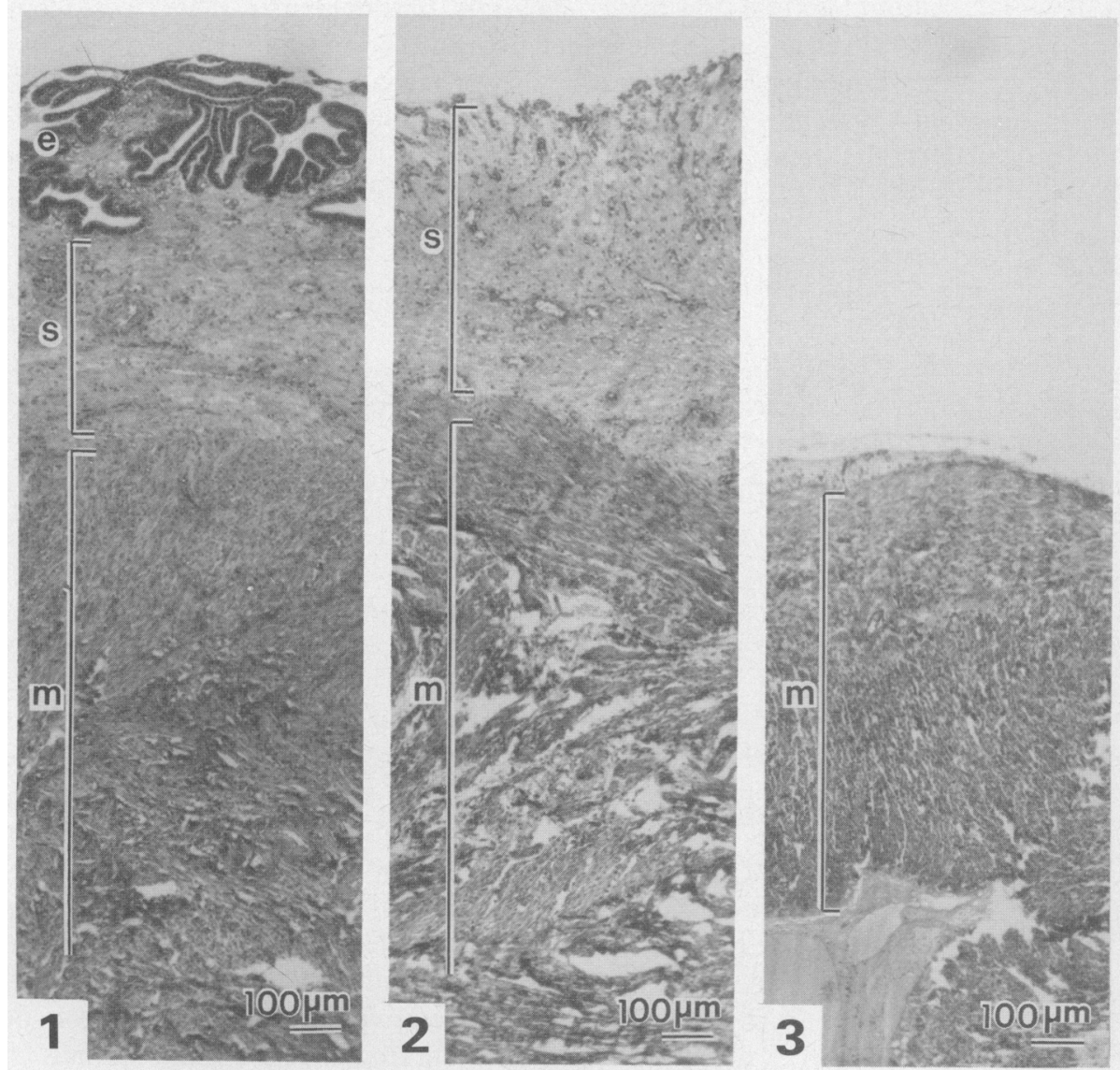

Histology of segments of the everted uterus from a rabbit at Day 4 of pregnancy, at 3 stages during the isolation of endometrial epithelial and stromal cells.

Fig. 1. Before cell separation the epithelium (e), stroma (s) and myometrium (m) are intact. Fig. 2. After incubation in pancreatin/trypsin, the epithelium has been removed and the stroma and myometrium remain.

Fig. 3. After incubation in trypsin/EDTA, stroma is also removed, but the myometrium is unaffected. 
PLATE ?
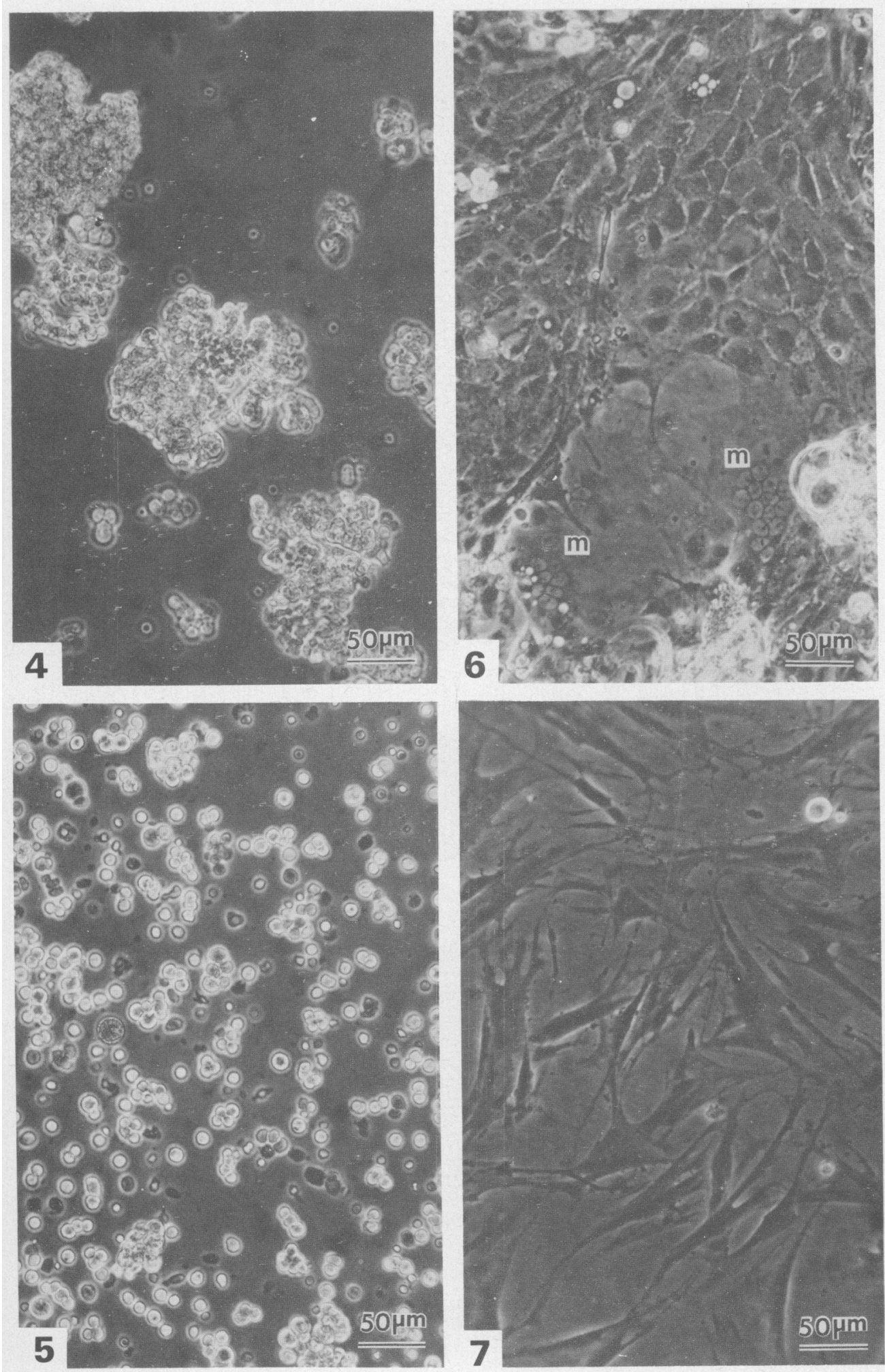


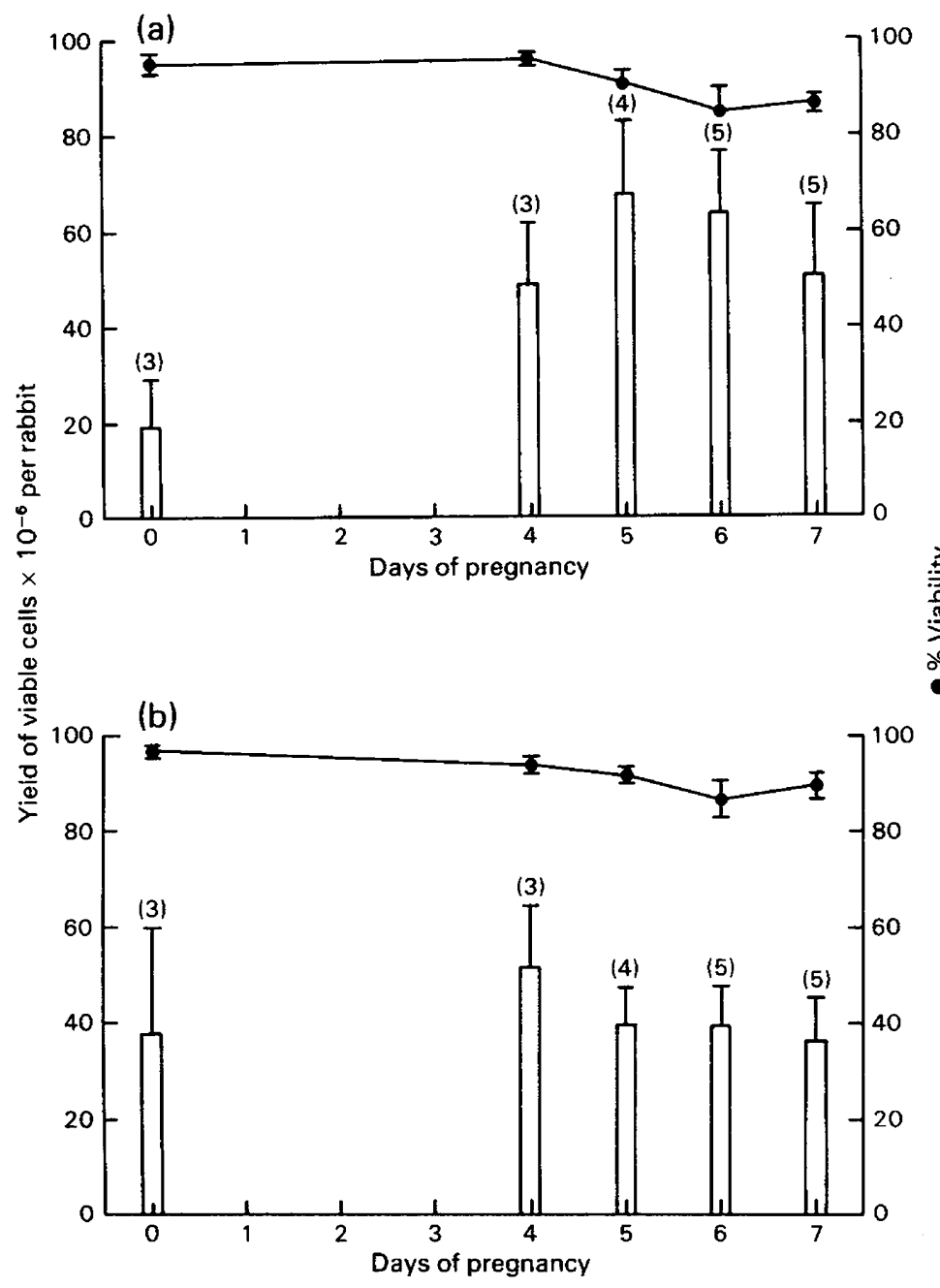

Text-fig. 1. Yield of (a) epithelial and (b) stromal cells isolated from rabbit uteri on different days of pregnancy. Columns are mean values (no. of animals in parentheses) and vertical lines indicate 1 s.e.m. Also shown are the mean \pm s.e.m. viabilities of the cells in these preparations determined by trypan blue exclusion.

\section{PLATE 2}

Separated endometrial cells prepared from a rabbit at Day 6.5 of pregnancy. Cell morphology was not affected by gestational age except that multinucleated epithelial cells (m) were uncommon before Day 6.

Fig. 4. Epithelial cells immediately after isolation.

Fig. 5. Stromal cells immediately after isolation.

Fig. 6. Epithelial cells after 4 days in culture.

Fig. 7. Stromal cells after 4 days in culture. 


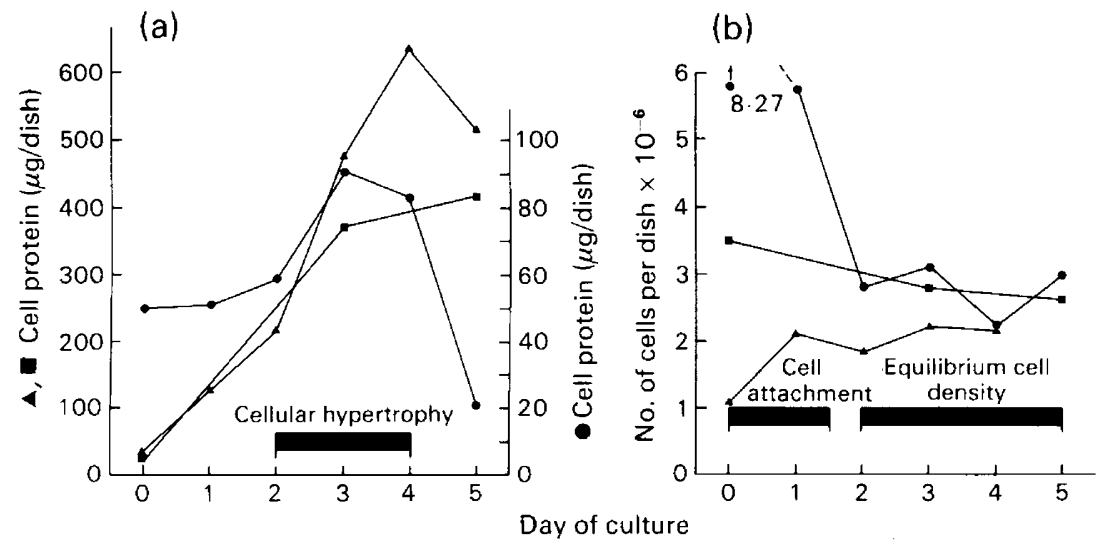

Text-fig. 2. Total protein (a) and cell number (b) calculated from total DNA per dish, assuming $5.3 \mathrm{pg} \mathrm{DNA} /$ cell of rabbit endometrial cells. The increase in total protein after 2 days of culture represents cellular hypertrophy.

\section{Ultrastructure of cells in culture}

Cells were examined by transmission electron microscopy after 6 days in culture, and representative micrographs are shown in Pl. 3, Figs 8-11. Epithelial cells had a microvillous surface (PI. 3, Fig. 8) with some coated pits, and, where cells were in contact, there were long regions of desmosomes (P1. 3, Fig. 9) with the membranes interdigitating in complex patterns. Numerous mitochondria, microtubules, coated vesicles and granules of electron-dense material were seen ( $\mathrm{Pl}$. 3, Fig. 8). Polysomes were abundant (P1. 3, Fig. 9), but endoplasmic reticulum was scant, and neither Golgi bodies nor cilia were seen in this plane of section. Some lysosomes were seen, but in general the ultrastructure suggested good viability. The well-preserved nuclear membrane was frequently infolded and had many pores, nucleoli were large and prominent with a skein-like structure, and nuclear bodies were sometimes present. The main difference between the epithelial and stromal cells was in the structure of the plasmalemma, which in stromal cells lacked extensive microvilli (Pl. 3, Fig. 10) and junctional complexes between cells in contact (Pl. 3, Fig. 11). The ultrastructure of epithelial cells and stromal cells from different stages of pregnancy after 6 days in culture was fundamentally similar.

\section{PLATE 3}

Appearance by electron microscopy of rabbit endometrial cells after 6 days in culture. Cells from different stages of pregnancy had a similar appearance at the ultrastructural level.

Fig. 8. Epithelial cell from an animal at 6.5 days of pregnancy. Nucleoli (n) were large and complex, mitochondria $(\mathrm{m})$ and electron-dense granules $(\mathrm{g})$ were common, and some lysosomes (l) were seen. The apical surface had extensive microvilli (inset, $\mathrm{mv}$ ).

Fig. 9. Region of contact between two epithelial cells, showing numerous desmosomes (d) and the cytoplasm contained prominent cytoskeletal elements and many polysomes (p).

Fig. 10. Stromal cell from the same animal, showing well preserved ultrastructure and the absence of microvilli.

Fig. 11. Region of contact between two stromal cells, showing absence of junctional complexes between the plasma membranes (pm). 
PLATE 3
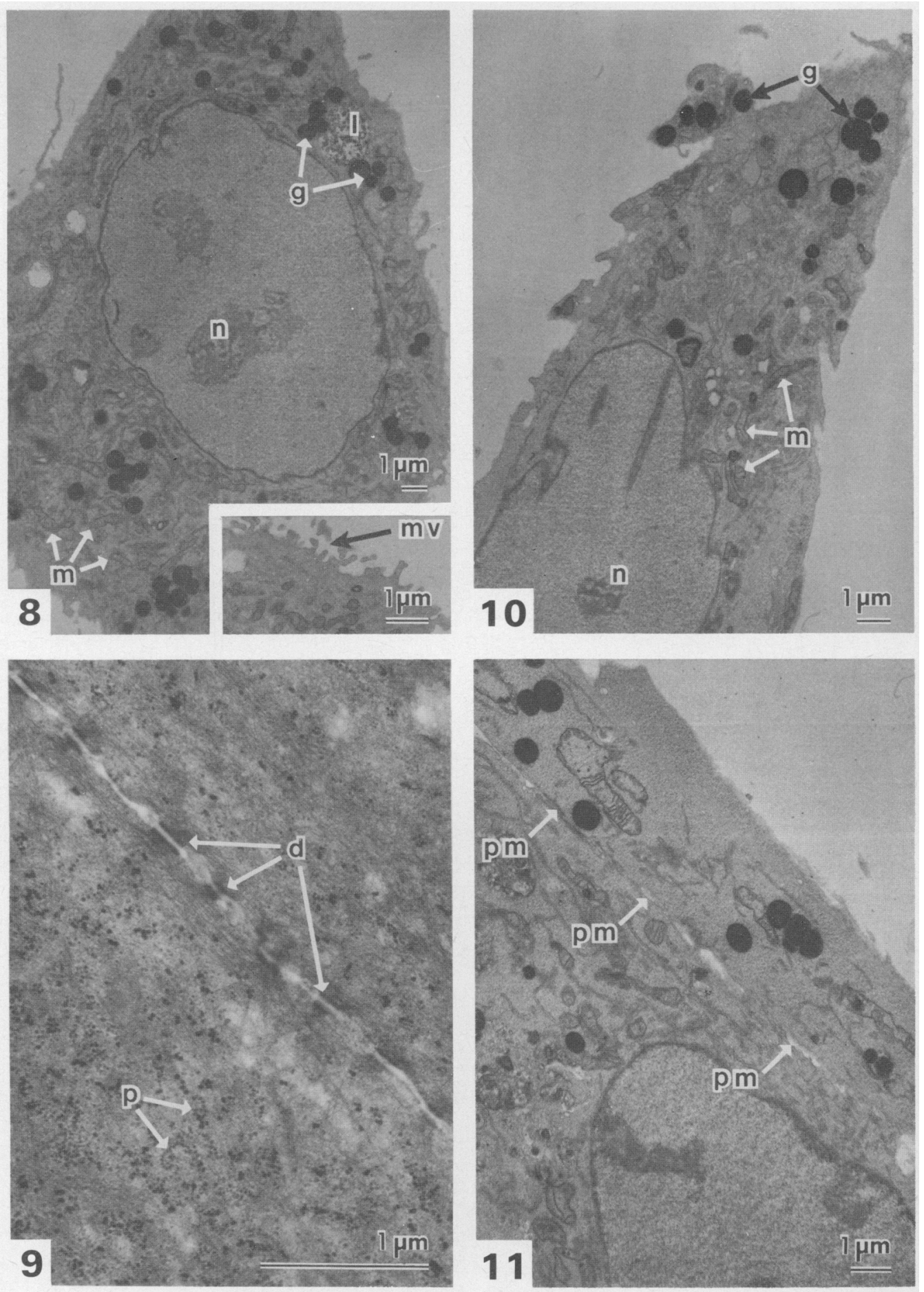

(Facing p. 156) 
PLATE 4
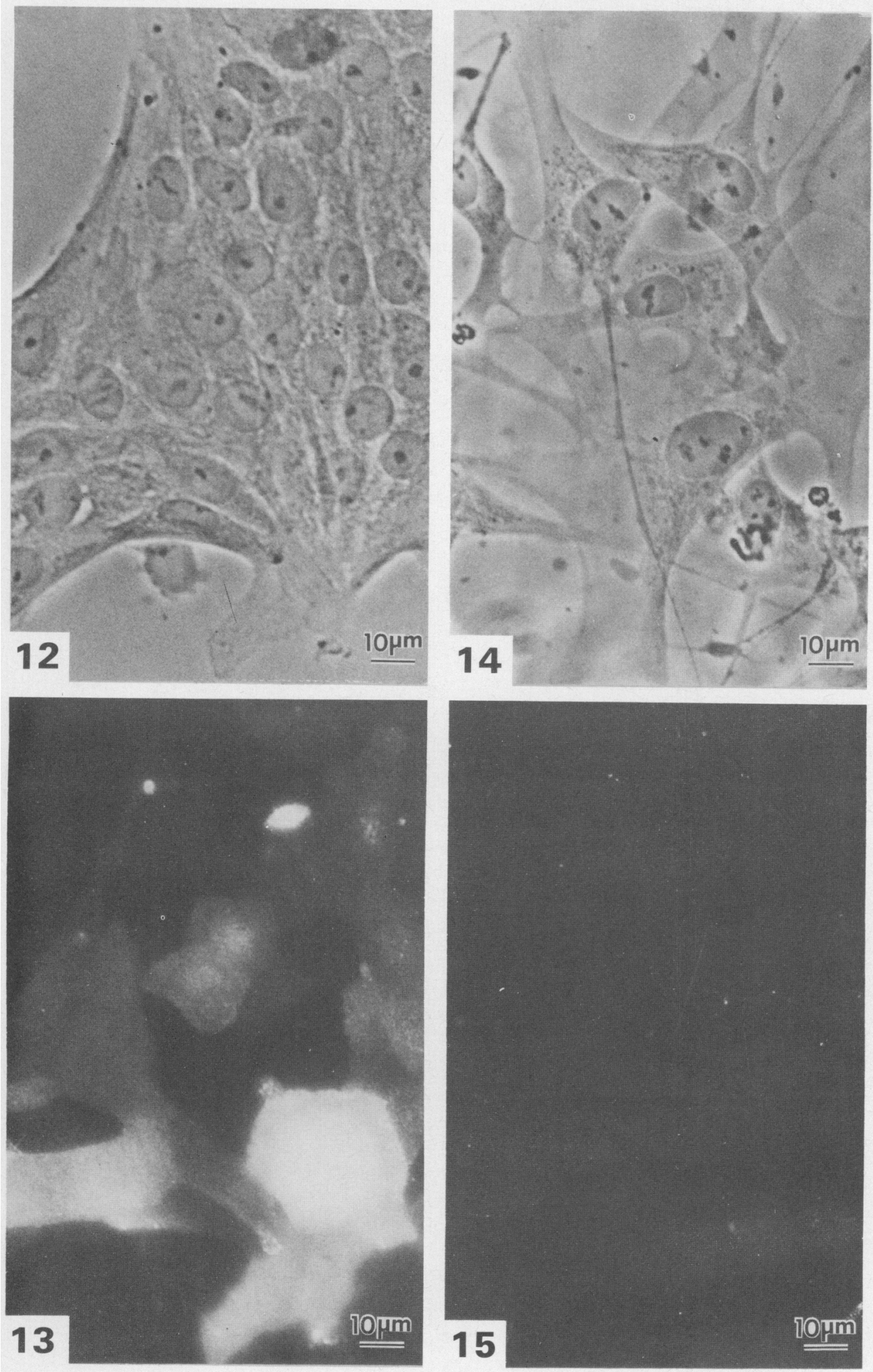

Downloaded from Bioscientifica.com at ๑4/26/2023 ๑9:18:20AM via free access 


\section{Production of uteroglobin}

Indirect immunofluorescent detection of uteroglobin is shown in Pl. 4, Figs 12-15. Stromal cultures were consistently negative. Cultures designated as epithelial by structural criteria showed a moderate level of homogeneous fluorescence over the cell surface, with different cells showing individual differences in intensity. In epithelial cells, a positive reaction was present in nonpregnant animals, at all stages of pregnancy, at all stages of culture, and in the absence as well as in the presence of FCS. All other control procedures described in 'Materials and Methods' abolished the immunofluorescence of epithelial cells. Initial production rate of uteroglobin during the first 2 days of culture varied with day of pregnancy, being maximal on Days 4 and 5 (Text-fig. 3a). The mean secretion rate for animals at Days 4 and 5 was significantly (by analysis of variance) higher than for non-pregnant animals, $(P<0.02)$ and animals at Days 6 and $7(P<0.001)$, which were
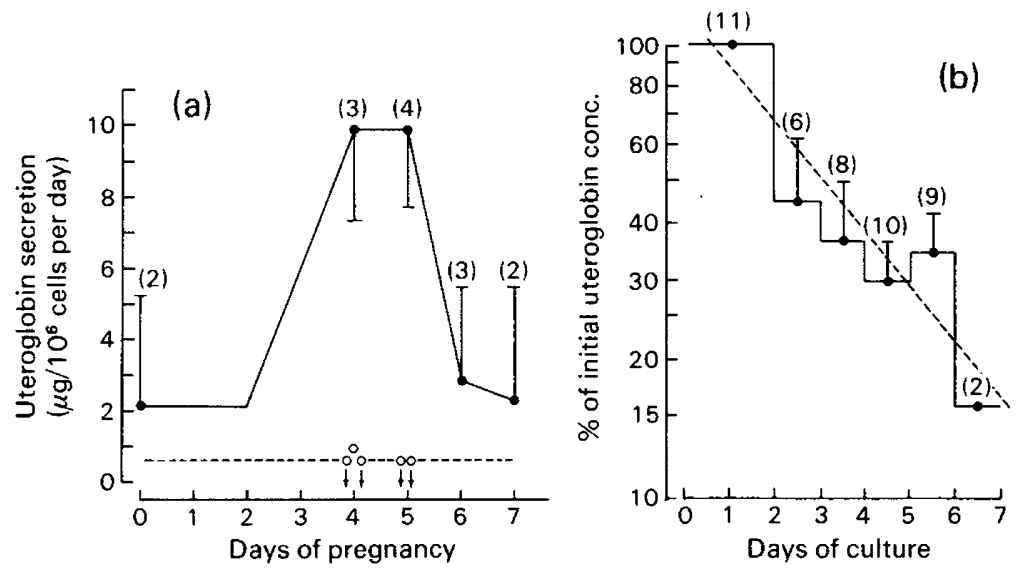

Text-fig. 3. Uteroglobin secretion into culture medium by rabbit uterine cell types (a) isolated on different days of pregnancy and (b) over time in culture. In (a) the results are expressed as $\mu \mathrm{g} / 10^{6}$ cells per day for the first 2 days of culture. Values for epithelial cells are means, and vertical lines show 1 s.e.m. (d.f. 13; no. of animals at each point in parentheses). Values for stromal cells are single points; $\downarrow$ indicates values below the limit of detection of the assay, which is shown by the broken horizontal line. The value for each animal was the mean of at least 2 dishes. The coefficient of variation between replicate dishes was $17 \cdot 1 \%(n=57)$. In (b) the uterine epithelial cells from animals at 0-7 days of pregnancy were plated and medium was changed after 2 days, then at subsequent times up to Day 7 in culture. The points are means over all days of pregnancy, expressed as a percentage of the mean initial secretion rate on Days 0-2 of culture (note logarithmic ordinate). Vertical lines show 1 s.e.m. (no. of animals at each point in parentheses). The broken line is a fitted linear regression of uteroglobin secretion against time in culture $(r=0 \cdot 933)$.

\section{PLATE 4}

Separated rabbit endometrial cells after 3 days in culture without serum, that had been formaldehyde-fixed and treated to demonstrate the presence of uteroglobin by indirect immunofluorescence. No effect of gestational age or stage of culture on fluorescence patterns was noted.

Fig. 12. Epithelial cells from a non-pregnant animal. Phase contrast.

Fig. 13. The same field as Fig. 12 showing positive immunofluorescence for uteroglobin.

Fig. 14. Stromal cells from Day 4 of pregnancy. Phase contrast.

Fig. 15. The same field as Fig. 14 showing the absence of uteroglobin immunofluorescence. 
not significantly different from each other. Stromal cells showed low or undetectable uteroglobin secretion rates at the time of highest production by epithelium. In 3 cultures of epithelial cells prepared from animals at Days 4 and 5 of pregnancy, the mean ( \pm s.e.m.) uteroglobin concentration in cells before culture, cells after 3 days in culture and medium after 3 days in culture was $0.099 \pm 0.040,0.085 \pm 0.035$ and $21.08 \pm 6.10 \mu \mathrm{g} /$ dish respectively.

After cells had attached, the uteroglobin secretion rate fell progressively during the subsequent days in culture, with a half-time of 2.5 days (Text-fig. 3b). As regression coefficients for (logtransformed) uteroglobin concentration in medium against days in culture were not significantly different for the different days of pregnancy, results for cultures from all days of pregnancy were combined.

\section{Discussion}

The method described has been characterized previously for the immature rat uterus (McCormack \& Glasser, 1980) based upon histology of uteri during cell dissociation and on phase contrast, scanning and transmission electron microscopy of cells. Where our characterization procedures overlap with the work of these authors, our equivalent cell fractions appear highly comparable, despite differences in gross uterine morphology between immature rats and pregnant rabbits.

The structure of endometrial cells in situ has been described thoroughly for non-pregnant, pseudopregnant and pregnant rabbits (Larsen, 1962; Davies \& Hoffman, 1973, 1975; Barberini, Sartori, Motta \& Van Blerkom, 1978). The epithelial cells in culture show remarkably similar structural features to those described for the cells in situ, even at a stage in culture (6 days) when degenerative changes might otherwise be expected to have begun. Features recognized in vivo by the above authors and observed in the present study of epithelium in vitro include a plasma membrane with microvilli and regions of intercellular contact consisting of interdigitated membranes with extensive desmosomes; cytoplasm with electron-dense granules, many microtubules and polysomes but little endoplasmic reticulum; nuclei with infolded membranes and numerous pores; and prominent nucleoli with the characteristic skein-like structure. The Golgi body is supranuclear in situ, which may explain why sections through the nucleus in vitro do not show this structure. Ciliation is common at certain stages of pregnancy, but cilia are only on the luminal surface; cilia were not seen in sections of the lateral membranes of cells in culture. Crystalline inclusions are present in glandular epithelial cells but not in luminal epithelium in vivo from Day 4 onwards (Davies \& Hoffman, 1975). That they were not observed in culture may indicate that our cultures are depleted of glandular epithelium. Alternatively, as these structures are hormonally induced (Hoffman \& Davies, 1973), they may not be maintained during culture for 6 days in the absence of hormones. Multinucleation occurs in the epithelium in situ at Day 6 of pregnancy (Larsen, 1962) and appears commonly in the cells in culture taken from this stage onwards.

The endometrial stromal cells in the rabbit are dispersed throughout an extensive amorphous ground substance that is replaced by a collagenous matrix by Day 7 of pregnancy (Davies \& Hoffman, 1973). This fact may explain the low yield of stroma relative to epithelium when compared with similar preparations from the rat (McCormack \& Glasser, 1980) and also the need to add a collagenase digestion step in the cell isolation protocol. The fibroblastic cell shape in situ is preserved in the stromal cells in culture, but the cellular shrinking and pyknosis that has been described as pregnancy progresses were not reflected in culture. From morphological evidence, we are confident that cell types are correctly identified and that the cells survive well in culture. The preparation method therefore yields cell fractions that are suitable for comparison between different stages of pregnancy despite the rather dramatic gestational age-related changes in gross uterine morphology. 
In immunohistochemical studies of the uterus, Kirchner (1979) has shown clearly, in nonpregnant rabbits and at all stages of pregnancy studied here, that uteroglobin is present in luminal and glandular epithelial cells of the endometrium but not in stroma or myometrium. Our immunofluorescence studies in cultures of isolated cells confirm the presence of uteroglobin in epithelial but not stromal cells at all stages of early pregnancy. Epithelial cells in culture, as in vivo, formed an irregular mosaic of cells with positive, negative and intermediate fluorescence. There is no systematic relationship between this pattern and the site of implantation in vivo (Kirchner, 1979). Our observations using immunofluorescence provide further evidence that our identification of cell types is correct, and the technique also gives a very sensitive indication of cross-contamination in cultures. Immunofluorescence, however, gives qualitative information only and does not reflect changes in production rate.

The immunofluorescence results were substantiated by quantitative analysis of uteroglobin concentration in culture medium. Epithelial cells synthesized uteroglobin at all stages of pregnancy studied, whereas stromal cells did not, providing biochemical evidence for the epithelial cellular origin of uteroglobin. The net rate of uteroglobin secretion rose from Day 0 to Day 4-5, then fell by Day 7 (Text-fig. 3a), in a pattern similar to that reported by radioimmunoassay of uteroglobin in uterine flushings and cultures of endometrial explants in vitro (Kao \& Bullock, 1981). In this study, we have not related the appearance of immunoreactive uteroglobin in medium to total protein synthesis or to incorporation of radioactive amino acids into uteroglobin, as we did earlier for endometrial explants (Kao \& Bullock, 1981). In both systems, however, only a small percentage of total immunoreactive uteroglobin is found in the tissue $(0.4 \%$ for cell monolayers), and the concentration in the medium is therefore a close approximation to the production rate of uteroglobin by epithelial monolayers. The decline in uteroglobin secretion with prolonged culture (Text-fig. 3b), which occurred irrespective of the stage of pregnancy at which cells were isolated, may reflect deterioration of cell function or progressive hormonal deprivation. Progesterone $\left(10^{-5} \mathrm{M}\right)$ and oestradiol $\left(10^{-7} \mathrm{M}\right)$ did not significantly alter the initial uteroglobin secretion rate of epithelial cells and did not affect the subsequent decline with time in culture (data not shown).

Rabbit endometrial cells prepared by this method exhibit at least one pregnancy-stage specific change in functional differentiation, namely uteroglobin secretion. We hope this method may prove also to be suitable for studying other stage-specific changes, such as alterations in cell surface proteins in early pregnancy.

This work was supported by funds from NIH grant HD 13663, and A.P.R. was in receipt of a Research Travel Grant from the Wellcome Trust. We thank Ms Linda Hall for excellent technical assistance; Mr Russell Edwards for electron microscopy (Center for Population Research and Reproductive Biology (HD 07495)); and Dr Bill Brinkley for help with and interest in the ultrastructural studies.

\section{References}

Barberini, F., Sartori, S., Motta, P. \& Van Blerkom, J. (1978) Changes in the surface morphology of the rabbit endometrium related to the estrous and progestational stages of the reproductive cycle. Scanning and transmission electron microscopic study. Cell Tiss. Res. 190, 207222.

Bullock, D.W., Woo, S.L.C. \& O'Malley, B.W. (1976) Uteroglobin messenger RNA: translation in vitro. Biol. Reprod. 15, 435 443.

Burton, K. (1956) A study of the conditions and mechanism of the diphenylamine reaction for the colorimetric estimation of deoxyribonucleic acid. Biochem. J. 62, 315-322.
Carlson, R.W., Wada, H.G. \& Sussman, H.H. (1976) The plasma membrane of human placenta. Isolation of microvillous membrane and characterization of protein and glycoprotein subunits. J. biol. Chem. 251, $4139-4146$.

Davies, J. \& Hoffman, L.H. (1973) Studies on the progestational endometrium of the rabbit. I. Light microscopy Day 0 to Day 13 of gonadotropin-induced pseudopregnancy. Am. J. Anat. 137, 423-445.

Davies, J. \& Hofiman, L.H. (1975) Studies on the progestational endometrium of the rabbit. II. Electron microscopy Day 0 to Day 13 of gonadotropin-induced pseudopregnancy. Am. J. Anat. 142, 335 336 . 
Gerschenson, L.E., Berliner, J.A. \& Yang, T. (1974) Diethylstilbestrol and progesterone regulation of cultured rabbit endometrial cell growth. Cancer Res. 34, 2873-2880.

Glossman, H. \& Gips, H. (1974) The preparation of brush border membranes from rat kidney using an aqueous two-phase polymer system. Naunyn-Schmiederbergs Arch. exp. Path. Pharmak. 282, 439-444.

Hewitt, K., Beer, A.E. \& Grinnell, F. (1979) Disappearance of anionic sites from the surface of the rat endometrial epithelium at the time of blastocyst implantation. Biol. Reprod. 21, 691-707.

Hofiman, L.H. \& Davies, J. (1973) Hormone induced crystalline inclusions in uterine epithelium. In Proc. 31st Ann. Electron Microscopy Soc. Am., pp. 560-561. Ed. C. J. Arceneaux. Claitor's Publishing Div., New Orleans.

Hynes, R.O. (1973) Alteration of cell-surface proteins by viral transformation and by proteolysis. Proc. natn. Acad. Sci. U.S.A. 70, 3170-3174.

Kao, L.W.L. \& Bullock, D.W. (1981) Rates of uteroglobin synthesis by endometrial explants from different days of early pregnancy in the rabbit. Biol. Reprod. 25, 820-824.

Kirchner, C. (1979) Immunohistochemical localization of secretory proteins in the endometrial epithelium of the rabbit. Cell Tiss. Res. 199, 25-36.

Larsen, J.G. (1962) Electron microscopy of the uterine epithelium in the rabbit. J. Cell Biol. 14, 49-64.

Lowry, O.H., Rosebrough, W.T., Farr, A.L. \& Randall, R.J. (1951) Protein measurement with the Folin phenol reagent. J. biol. Chem. 193, 265-275.
Mancini, G., Carbonara, A.O. \& Heremans, J.F. (1965) Immunochemical quantitation of antigens by single radial immunodiffusion. Immunochemistry 2, 235254.

McCormack, S.A. \& Glasser, S.R. (1980) Differential response of individual uterine cell types from immature rats treated with estradiol. Endocrinology 106, 1634-1649.

Mullins, D.E., Horst, M.N., Bazer, F.W. \& Roberts, R.M. (1980) Isolation and characterization of a plasma membrane fraction derived from the luminal surface of the pig uterus during the estrous cycle and pregnancy. Biol. Reprod. 22, 1181-1192.

Sherman, M. (1978) Implantation of mouse blastocysts in vitro. In Methods in Mammalian Reproduction, pp. 247-257. Ed. J. C. Daniel, Jr. Academic Press, New York.

Snedecor, G.W. (1952) Queries, 92. (Determination of precision of a chemical assay method.) Biometrics $\mathbf{8}$, 85-86.

Van Blerkom, J. \& Chavez, J. T. (1981) Morphodynamics of outgrowths of mouse trophoblast in the presence and absence of a monolayer of uterine epithelium. Am. J. Anat. 162, 143-155.

Wisher, M.H. \& Evans, W.H. (1975) Functional polarity of the rat hepatocyte surface membrane. Isolation and characterization of plasma membrane subfractions from the blood-sinusoidal, bile canalicular and contiguous surfaces of the hepatocyte. Biochem. J. 146, 375-388.

Received 1 June 1982 